approach bascd on the clinical and biochemical characteristics of this condition. J. Perinat. Med. 2: 147 (1974).

18. Schmidt, G. and Tannhauser, S. J.: A method for the determination of deoxvribonucleic acid, ribonucleic acid, and phospho-proteins in animal tissuc. J. Biol. Chem. 161:83 (1945)

19. Suzuki, K.. Horiguchi, T.. Comas-Urrutia, A. C.. Mueller-Heubach, E., Morishima. H.. and Adamsons. K.: Pharmacology effects of nicotine upon the fetus and mother in the rhesus monkey. Am. J. Obstet. Gynecol.. 111(8): $1092(1971)$.

20. U.S. Department of Hcalth. Education and Welfare: Pregnancy and Infant Health. Reprinted from "Smoking and Health: A Report of the Surgeon General". Chap. 8. p. 11 (1979).

21. Wagner, B. and Chouroulinkov, I.: The effect of cigarette smoke inhalation upon mice during pregnancy. Rev. Eur. Etud. Clin. Biol. 18.943 (1972).

22. Wigglesworth. J. S.: Experimental growth retardation in the foetal rat. J. Path. Bact.. 88 (1): 1 (1964).

23. Wigglesworth, J. S.: The effect of placental insufficiency on the fetal lung. J. Clin. Pathol. (suppl), 10:27 (1976).
24. Winik. M.: Cellular growth of the placenta as a indicator of abnormal fetal growth. In: K. Adamsons Diagnosis and Treatment of Fetal Disorders. pp 83-101 (Springer-Verlag, New York 1969).

25. Younoszai, M. K.. Peloso, J., and Haworth, J. C.: Fetal growth retardation in rats exposed to cigarette smoke during pregnancy. Am. J. Obstet. Gynacol. 104: 1207 (1969).

26. Zambrana. M. A. and Greenwald, G. S.: Effects of fetal, ovarian and placental weight of various number of fetuses in the rat. Biol. Reprod.. 4: 216 (1971).

27. The authors thank Mr. Frank Mallavo for technical assistance.

28. Requests for reprints should be addressed to: Dr. Jorge A. Bassi, Columbia University, College of Physicians and Surgeons. Institute of Human Nutrition, 630 West 168th Street, Black Building--Room 262, New York. NY 10032.

29. This research was supported by the National Institutes of Health. Grant No. HD-13063.

30. Received for publication August 31, 1982

31. Accepted for publication May 9, 1983

\title{
Detection of the Cystic Fibrosis Protein by Isoelectric Focusing of Serum and Plasma
}

\author{
R. GRATAROLI. O. GUY-CROTTE, C. GALABERT, AND C. FIGARELla(15) \\ Unité de Recherches de Pathologie Digestive, INSERM U-31, 46. Boulevard de la gave, 13258 \\ Marseille Cedex 09, France
}

\begin{abstract}
Summary
We used the isoelectric focusing method developed by Wilson to analyze serum from individuals homozygous or heterozygous for cystic fibrosis. The presence of cystic fibrosis protein (CFP) was found in 37 out of 52 homozygous and 24 out of 34 heterozygous patients, which leads to a frequency of $71 \%$ for both families. Five out of $\mathbf{2 4}$ controls were found positive. The same study, performed on 26 plasma samples collected from the same patients, demonstrated that the detection of CFP is possible in plasma as well as in serum. Our results confirm the presence of a protein "marker" of CF in serum, but also underlines the lack of sensitivity of the isoelectric focusing technique to be used for diagnosis.
\end{abstract}

\section{Abbreviations}

CFP, cystic fibrosis protein

IEF, isoelectric focusing

Cystic fibrosis, characterized by a generalized metabolic disorder, is one of the most prevalent genetic diseases in the Caucasian population. An incidence of 1 in 2000 live births has been reported (3), and approximately 1 in 20 of the population is a carrier of the gene or heterozygote (8).

In 1973, Wilson et al. (8) detected a "cystic fibrosis factor" now designated "cystic fibrosis protein" in serum using IEF in thin layer polyacrylamide gels. Other studies from this laboratory $(9,11)$ characterized this CFP as having a pI of 8.4 , a molecular weight between $3500-10,000$, and a close association with IgG in serum. The importance of these findings prompted different laboratories to reproduce this IEF technique but with widely varying success $(2,5,7)$. Recently, Nevin et al. (4) confirmed the CFP frequency reported by Wilson using the same IEF technique. Because of several unsuccessful reports, another set of experiments to confirm the presence of this protein in serum was necessary. Furthermore, the protein had never been characterized in plasma. Only Wilson recommended that samples obtained from heparinized or citrated blood not be used (9); therefore, it is of interest to study the presence of CFP in plasma and serum from the same patients for a further understanding of the nature of CFP, and to eliminate the possibility of the origin of CFP by proteolysis during blood clotting.

\section{MATERIALS AND METHODS}

Material. Sera from $52 \mathrm{CF}$ patients were supplied by J. P. Chazalette (Giens) and R. Gilly (Lyon). Diagnosis of the disease was established by clinical criteria and an abnormal sweat test. Sera from 34 obligate heterozygotes and 24 controls were studied in parallel.

Preparation of sera and plasma. All sera were carefully collected as described by Wilson et al. (9). After collection, all samples of venous blood were immediately cooled at $4{ }^{\circ} \mathrm{C}$ and allowed to clot in glass tubes for $4-6 \mathrm{~h}$. The samples were then centrifuged at $1700 \mathrm{~g}$ for $10 \mathrm{~min}$ at $4^{\circ} \mathrm{C}$ and the serum was transferred by aliquots into plastic tubes, then frozen and stored at $-75^{\circ} \mathrm{C}$

Plasma $(5 \mathrm{ml})$ from the same patients $(12 \mathrm{CF}$ patients, nine heterozygotes, and five controls) were collected in tubes containing $25 \mu \mathrm{l}$ heparin $(50,000 \mathrm{IU})$ and immediately centrifuged at $400 \mathrm{~g}$ for $5 \mathrm{~min}$, then at $3000 \mathrm{~g}$ for $10 \mathrm{~min}$ at $4^{\circ} \mathrm{C}$. After centrifugation, plasma samples were stored as described for serum.

$I E F$. IEF was performed in thin layer polyacrylamide gels 
using the pH gradient 5-10, recommended by Wilson in his first publication (9) and prepared with the following mixture of Ampholine carrier ampholytes: $1.5 \mathrm{ml} \mathrm{pH} \mathrm{5-8,1} \mathrm{ml} \mathrm{pH} \mathrm{8-9.5,}$ $0.25 \mathrm{ml} \mathrm{pH} 7-9$, and $0.25 \mathrm{ml} \mathrm{pH} \mathrm{9-11.} \mathrm{To} \mathrm{prepare} \mathrm{the} \mathrm{gel} \mathrm{this}$ mixture was added to $7.4 \mathrm{ml}$ stock solution of acrylamide $(25 \mathrm{~g} /$ $100 \mathrm{ml}), 8 \mathrm{ml}$ bisacrylamide $(1.0 \mathrm{~g} / 100 \mathrm{ml}), 15 \mathrm{~g}$ cristallised urea, and distilled water up to $50 \mathrm{ml}$ final volume. After deaeration under reduced pressure for $4-5 \mathrm{~min}$ with mild agitation $0.83 \mathrm{ml}$ of $1 \%$ ammonium persulfate, $3.3 \mathrm{ml}$ of $0.004 \%$ riboflavine, and $0.06 \mathrm{ml}$ of TEMED were added to induce polymerization. This mixture results in a gel with $\mathrm{T}=4 \%$ and $\mathrm{C}=4 \%$ (13) containing 4.9 $\mathrm{M}$ urea and $2.2 \%$ Ampholine-carrier ampholytes.

After polymerization for one night, the glass moulding plate was removed, duplicate samples were applied, and electrofocusing was carried out for $2 \mathrm{~h}$ at $25 \mathrm{~W}$ constant power using the LKB Multiphor. The electrolytes used were $1 \mathrm{M} \mathrm{PO}_{4} \mathrm{H}_{3}$ for the anode and $1 \mathrm{M} \mathrm{NaOH}$ or $5 \%$ TEMED for the cathode. Subsequently, the gel was simultaneously fixed and stained in a solution of $45 \mathrm{~g}$ trichloracetic acid, $13.5 \mathrm{~g}$ sulphosalicylic acid, 0.45 g Coomasie Blue $\mathrm{R}$ in $135 \mathrm{ml}$ methanol, and $280 \mathrm{ml}$ distilled water. The staining was carrried out in boiling water for $15 \mathrm{~min}$. After cooling to room temperature in the staining solution, the destaining of the gel was performed with the mixture methanol/ water/acetic acid $(6: 13: 1, \mathrm{v} / \mathrm{v})$.

Samples. Twenty five microliters of each serum were applied to the gel. Each sample contained $200-400 \mu \mathrm{g}$ of IgG determined by single radial immunodiffusion using Tri-partigen IgG plates (Behring).

\section{RESULTS}

Analysis of sera. Figure 1 represents an electrofocusing plate containing different serum from CF patients, heterozygote carriers for $\mathrm{CF}$, and normal control subjects. The $\mathrm{CF}$ protein band, the most basic protein of serum, is clearly visible in samples from $\mathrm{CF}$ patients, especially in samples CF2, CF5, CF6, and CF7 (shown with arrow). In samples 1, 3, and 4 the band is faint and more diffuse. In the two samples of normal serum the band is completely absent and the same pattern is obtained with two samples from heterozygotes $(\mathrm{Hz} 3-\mathrm{Hz} 4)$. For $\mathrm{Hzl}$ and $\mathrm{Hz} 2$ the result is less evident. This figure shows a classical pattern of IEF of serum and points out the difficulty in evaluating the presence of CFP. Figure 2 shows an enlarged area of the CFP band after

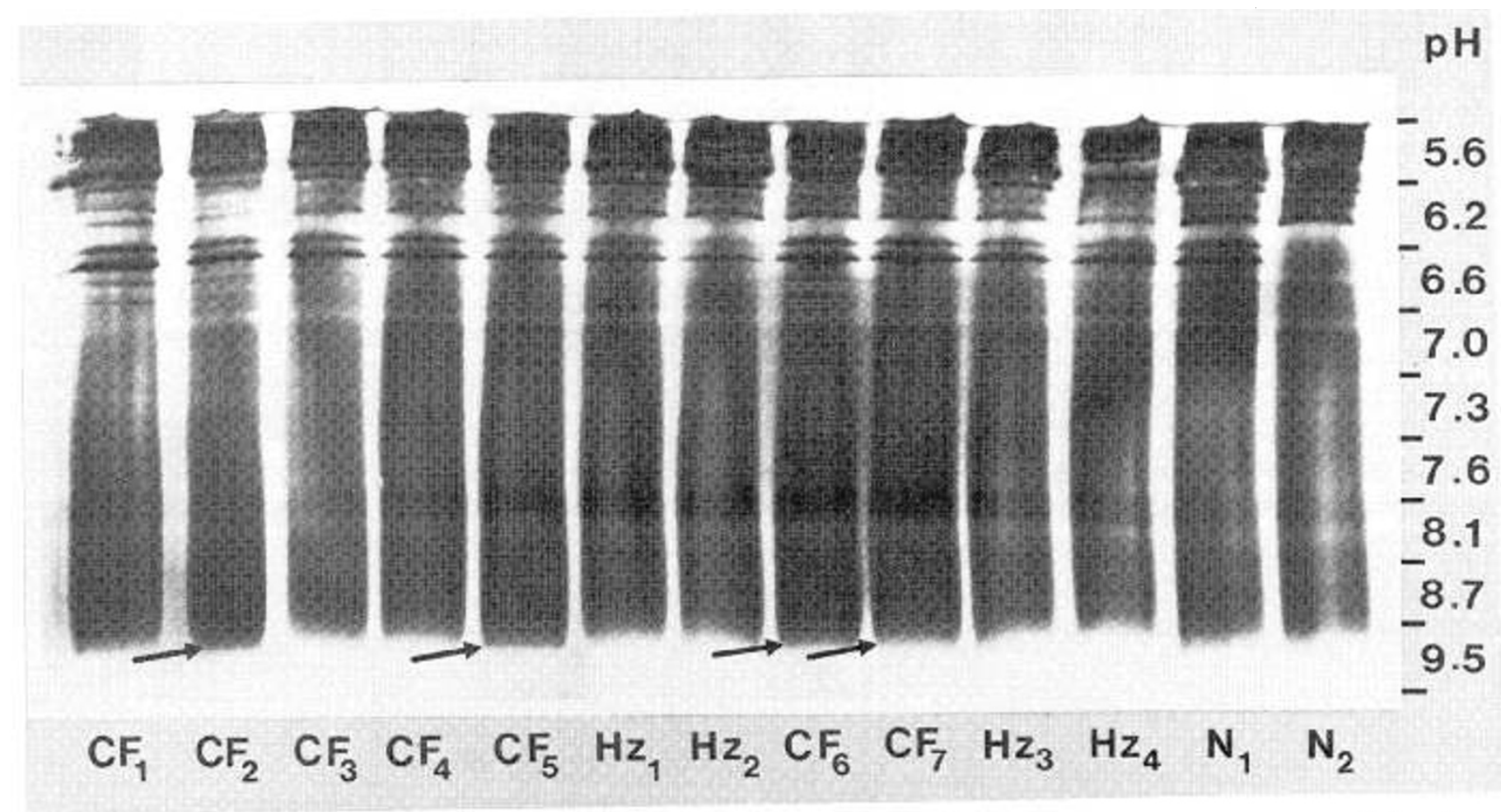

Fig. 1. Isoelectric focusing pattern of serum proteins. Seven samples from CF patients (CF), four samples from heterozygotes (Hz), and two controls $(\mathrm{N})$ are represented. The $\mathrm{pH}$ gradient is shown to the side. 
electrofocusing of sera from one $\mathrm{CF}$ patient and one normal control. On this CF sample, the additional protein band is evident. But, because the results were not always obvious, each sample was assayed at least three times and more when doubtful results were obtained. In most serum samples the amount of IgG was $300 \mu \mathrm{g}$ as recommended by Wilson (9), but the analysis of results shows that above this minimal amount the visualization of the CFP band is not modified. The results of the CFP detection in 101 sera are summarized in Table 1 . They are significantly different $\left(2 P \leqslant 0.001\right.$ by $\chi^{2}$ test $)$ between $C F$ homozygotes or heterozygotes and normal controls.

Analysis of plasma. The electrofocusing analysis of eight different plasma is presented in Figure 3. Some samples (CF4, CF6, CF7, Hz3) came from the same patients as did the serum and

Table 1. Serum positivity for cystic fibrosis protein as determined by isoelectric focusing

\begin{tabular}{lrcc}
\multicolumn{1}{c}{ Patients $(n)$} & + & - & $\%(+)$ \\
\hline Normal controls (24) & 5 & 19 & 20 \\
CF heterozygotes (34) & 24 & 10 & 71 \\
CF homozygotes (52) & 37 & 15 & 71 \\
\hline
\end{tabular}

are presented in Figure 1. The same protein band is present in most CF plasma and in some heterozygote plasma. Table 2 summarizes the IEF results of 26 patients whose plasma and serum have been studied. Only three patients gave opposite results in serum and plasma. Different tests used (sign test, exact probability of Fisher) did not indicate any significant difference between results obtained with serum and with plasma; therefore, the $\mathrm{CF}$ protein can be characterized in plasma as well as in serum, but the difficulty remains the same.

\section{DISCUSSION}

Our results confirm the presence of a peculiar protein in the sera of CF patients and obligate heterozygotes; however, we did not find the same CFP frequency as that reported by Wilson (10) and by Nevin (4). The frequencies in homozygotes $(71 \%$ instead of more than $90 \%$ ) and heterozygotes ( $71 \%$ instead of $85 \%$ ) are lower, and alternatively the frequency in controls is higher $(20 \%$ instead of $8 \%$ ). This last result can be explained by the small number of control subjects studied and also by the presence of at least one positive control with a known bronchiectasis. By contrast we think that our results obtained with the sera of $\mathrm{CF}$ patients and obligate heterozygotes are probably due to the lack

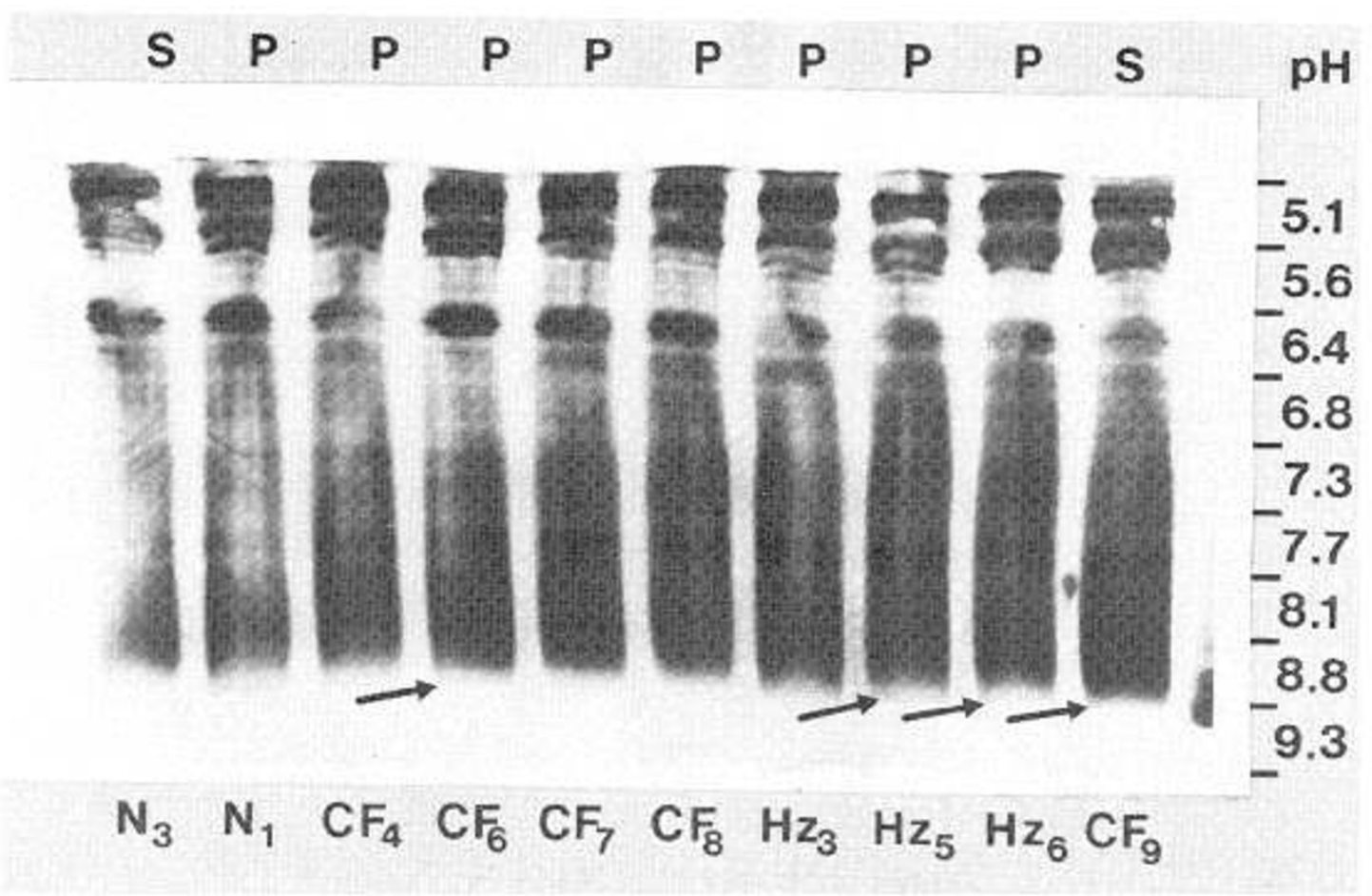

Fig. 3. Isoelectric focusing pattern of plasma proteins. P. Four samples from CF patients (CF), three samples from hetcrozygotes (Hz) and one control (N) are represented. Two serum samples. S. (N3 and CF9) are given for comparison.

Table 2. Comparison of the positivity for cystic fibrosis protein between serum and plasma

\begin{tabular}{|c|c|c|c|c|c|c|c|c|}
\hline \multicolumn{3}{|c|}{ CF homozygotes } & \multicolumn{3}{|c|}{ CF heterozygotes } & \multicolumn{3}{|c|}{ Normal controls } \\
\hline Sample & Plasma & Serum & Sample & Plasma & Serum & Sample & Plasma & Serum \\
\hline 1 & + & - & 1 & + & + & 1 & - & - \\
\hline 2 & + & + & 2 & + & + & 2 & + & + \\
\hline 3 & + & - & 3 & - & + & 3 & - & - \\
\hline 4 & + & + & 4 & - & - & 4 & - & + \\
\hline 5 & + & + & 5 & + & + & 5 & - & - \\
\hline 6 & - & - & 6 & + & + & & & \\
\hline 7 & + & + & 7 & + & + & & & \\
\hline 8 & + & + & 8 & + & + & & & \\
\hline 9 & + & + & 9 & - & - & & & \\
\hline 10 & + & + & & & & & & \\
\hline 11 & + & + & & & & & & \\
\hline 12 & + & + & & & & & & \\
\hline
\end{tabular}


of sensitivity of the IEF technique as suggested by others. We also tried the modified technique of Wilson et al. (10) with a $\mathrm{pH}$ 2.5-10.0 gradient instead of a $\mathrm{pH} \mathrm{5-10} \mathrm{gradient} \mathrm{and} \mathrm{with} \mathrm{a}$ prefocus $30 \mathrm{~min}$ at 300 volts, but the detection of the CFP band was not improved.

Recently, this CFP specific material, isolated from polyacrylamide gel after electrofocusing, has been used with success by different groups to develop a quantitative immunoassay. Manson and Brock $(1,2)$ have raised antisera in guinea pigs and Wilson in mice (12). Both antisera allowed a quantitative distinction between $C F$ homozygotes, heterozygotes, and controls. Even if there are still a number of unsolved problems such as blood collection and antiserum supply (1), their data, which shows a difference in levels of CFP strongly argue that this protein may be a marker of cystic fibrosis. Our characterization of CFP in plasma as well as in serum demonstrates that this low molecular weight protein is present in blood before blood clotting and could permit a better standardization of blood collection, which looks critical for its evaluation.

In conclusion, we agree with many workers that the IEF technique is too delicate and not sufficiently sensitive to be used for diagnosis. This technique remains, however, the first step in identifying the CFP which seems to be closely associated with the $C F$ gene and whose characterization would allow future investigation of the basic defect of the disease.

\section{REFERENCES AND NOTES}

1. Bullock. S.. Havward, C. Manson. J., Brock. D. J. H.. and Racburn, J. A Quantitalive immunoassays for diagnosis and carrier detection in cystic fibrosis Clin Genet. 21:336(1982)

2. Manson. J. C. and Brock. D. J. H.: Development of a quantitative immunoassay for the cystic tibrosis gene. Lancet. Feh. I6: $330(1980)$.
3. Nevin. G. B., Nevin, N. C., and Remond. A. O.: Cystic fibrosis in Northern Ireland. J Med. Genet.. /6: 122 (1979).

4. Nevin. G. B., Nevin, V. C.. Redmond, A. O., Young, I. R., and Tully, G. W. Detection of cystic fibrosis homozygotes and heterozygotes by serum isoelectrofocusing. Hum. Genet. 56: 387 (1981).

5 Scholey J. Applegarth. D. A. Davidson. A. G. F.. and Wong. L. T. K.: Detection of cystic fibrosis protein by electrofocusing. Pediatr. Res. 12: 800 (1978).

6. Steinberg. A. G. and Brown, D. C.: On the incidence of cystic fibrosis of the pancreas. Am. J. Hum. Genet., 12: 416 (1960).

7. Thomas J M. Merritt. A. D., and Hodes, M. E.: Electrophoretic analysis of serum protein in cystic fibrosis. Pediatr. Res.. 11: 1148 (1977).

8. Wilson, G. B. Jahn, T. L.. and Fonseca, J. R.: Demonstration of serum protein Wilson, G. B.. Jahn, T. L.. and Fonseca, J. R.: Demonstration of serum protein amide gels. Clin. Chim. Acta. 49: 79 (1973).

9. Wilson G. B Fudenberg, H. H.. and Jahn. T. L.: Studies on cystic fibrosis using isolelectric focusing. An assay for detection of cystic fibrosis homozygotes and heterozvgote carriers from serum. Pediatr. Res. 9: 635 (1975).

0. Wilson. G. B.. Arnaud. P.. and Fudenberg. H. H.: Improved method for detection of cystic fibrosis protein in serum using LKB multiphor electrofocusing apparatus. Pediatr. Res., 11: 986 (1977).

11. Wilson $G$ B. Cystic fibrosis protein a confirmed diagnosis marker for detecting heterozygote carriers: significance in relation to future screening and to a proposed primary defect in alpha 2 -macroglobulin. Pediatr. Res. 13: 1079 (1979).

12. Wilson G. B. Monospecific antisera hybridoma antibodies, and immunoassays for cystic fibrosis protcin. Lancet. 9:313(1980).

13. $\% \mathrm{~T}=$ grams of acrylamide + grams of bisacrylamide $/ 100 \mathrm{ml}$ of solution: $\% \mathrm{C}$ $=100$ times grams of bisacrylamide $/ 100 \mathrm{ml}$ solution $/ \mathrm{T}$. Nomenclature according to Vesterberg, $\mathrm{O}$. and NISE, G.: Urinary proteins studied by use of isoelectric focusing. 1/ Tubular malfunction in association with exposure to cadmium. Clin. Chem. 19:1179 (1973).

14. The authors thank J. P. CHAZALETTE (Giens), R. GILLY and I. GARCIA (Lyon) for supplying them with sera and plasma. A grant from the AFLM (Association Française de lutte contre la mucoviscidose) is gratefully acknowledged.

15 Requests for reprints should be addressed to: Doctor Catherine Figarella, INSERM U-31, 46. Boulevard de la Gaye. 13258 MARSEILLE CEDEX 09 INSERM U
(FRANCE)

16. Received for publication January 12, 1983.

17. Accepted for publication August 17. 1983.

\title{
Changes in the Growth-Promoting Activity of Human Milk during Lactation
}

\author{
LEANNA C. READ. ${ }^{(37)}$ FAYE M. UPTON, GEOFFREY L. FRANCIS, JOHN C. WALLACE. \\ GEOFFREY W. DAHLENBERG, AND F. JOHN BALLARD \\ CSIRO Division of Human Nutrition [L.C.R., G.L.F., F.J.B.], University of Adelaide, Departments of \\ Biochemistry [F.M.U., J.C.W.], and Pediatrics /G.W.D.J Adelaide, S.A. 5000, Australia
}

\section{Summary}

We measured the concentrations of protein, insulin, and epidermal growth factor (EGF) in human milk from mothers delivering at term. Samples were obtained from $\mathrm{d} 1$ (colostrum) to $\mathrm{d}$ 42 after birth. Human colostrum contains very high concentrations of protein $[83.7 \pm 7.4 \mathrm{~g} / \mathrm{l}(\mathrm{SEM})]$, insulin $(3.75 \pm 0.88$ $\mathrm{nM})$, and EGF $(53.9 \pm 6.9 \mathrm{nM})$. Similar concentrations have been measured in prebirth milk. Insulin, EGF, and protein in milk decline rapidly during the first few days of lactation but remain constant thereafter. Although the concentrations of insulin and EGF in mature milk are only $10 \%$ of those in colostrum, they are considerably higher than in serum. We also showed that human milk has a growth-promoting activity in cultured cells, causing a stimulation of protein synthesis in $\mathrm{L6}$ myoblasts and
3T3-L1 fibroblasts and an increase in DNA synthesis in L6 cells and T47D breast cancer cells. This mitogenic activity declines as lactation progresses, with a similar time-course to the fall in insulin and EGF; however, the cell lines used here are not responsive to either of these two growth factors in the range of concentrations found in milk. This indicates that human milk also contains high concentrations of additional, unidentified growth factors. The occurrence of high concentrations of growth factors in milk suggests that they may be important for the proliferation and differentiation of infant tissues.

\section{Abbreviations}

EGF, epidermal growth factor

PBS, phosphate buffered saline 